\title{
Discourses in place: technology and language experts negotiating solutions for a language learning application
}

\author{
Maritta Riekki ${ }^{1}$ and Leena Kuure ${ }^{2}$
}

\begin{abstract}
This study explores the nature of collaboration between language students and technology developers while designing an application for language teaching. This project was part of a university course on language learning and teaching in technology-rich environments. An important aspect of the course was to help the university students to explore and extend their understandings of language teaching and being language teachers. One of the student teams on the course had the opportunity of acting as language (pedagogy) experts while working with technology experts, negotiating directions for the application under development. Such a collaborative relationship together with the support of the course was expected to provide the participants with new perspectives, helping them to detach themselves from narrow conceptions of language pedagogy. Video materials were stored from different phases of the project. The design concepts and reflection papers produced by the students were also used in the analysis. The research drew on nexus analysis. The findings suggest that multidisciplinary collaboration can be fruitfully integrated into language teacher education to provide the students with experiences and perspectives for assuming an active role in technology development for language learning, and, additionally for seeing this type of cooperation as an essential element of their language teacher professionalism.
\end{abstract}

Keywords: professional development, multidisciplinarity, sense making, nexus analysis. 


\section{Introduction}

As our technology-rich environments of everyday life and education are changing, language teachers also need to rethink their pedagogic roles, designs, and practices in a new light (Blin \& Jalkanen, 2014). One site for appropriating new kinds of language teacher professionalism is the development of applications for language learning/teaching together with technology specialists. Language teachers and researchers have been involved in numerous projects where new environments have been under construction and applied in practice (see ReCALL ${ }^{3}$ ). However, research in the field rather focuses on aspects of language learning and pedagogic approaches than on the development of technologies. Language teachers and students have been participating in technology development often as usability testers and focus group informants. It seems that language teachers could have a stronger role in developing technology-mediated learning environments for language pedagogy in the modern world. This, however, requires new kinds of expertise and agency in multidisciplinary collaboration, which the current language teacher education seldom supports concretely (Riekki, 2016).

This study focuses on collaboration between two teams, one with expertise in language pedagogy and the other in technology. The context for the study was a Master's level course on language learning and teaching in technology-rich environments where two technology developers were invited to work together with one of the project teams on the course, designing an application for use in language teaching. One of the developers was a doctoral student (ubiquitous computing) and the other a Master's student (information networks). The study draws on a nexus analysis (Scollon \& Scollon, 2004) and a multimodal (inter)action analysis (Norris, 2011) using multiple types of data. This allows exploring collaboration in situ as an aggregate of discourses echoing the past and emanating new discourses.

\section{Research materials and approach}

\subsection{Research materials}

The aim of this study was to shed light on the nature of collaboration between language students and technology developers. The language team joined the technology team not only to test the application but also to act as language teaching

3. https://www.cambridge.org/core/journals/recall 
specialists in the course of the design process. Different types of research materials were gathered, e.g. video materials from the planning, testing and evaluation sessions, which took place beyond the course meetings. In addition to the video data, reflection papers and design concepts written by the students were consulted.

\subsection{Research approach}

The research proceeded by examining the video data through the lens of nexus analysis, which sees social action and interaction as an intersection of interaction order, historical body, and discourses in place (Scollon \& Scollon, 2004). Discourses in place refers to the social semiotic meaning making that emerges in a social arrangement by which people come together. Interaction order implies the mutual relationships and power configurations between the participants. Historical body is used to describe the life experiences of the social actors involved in the action. Nexus analysis is characteristically ethnographic, yet historical, in its approach (Scollon \& Scollon, 2004). Some aspects of multimodal (inter)action analysis were also used in the examination of the research materials, so as to trace identity work arising in the collaborative situations (Norris, 2011).

\section{Discussion}

Riekki (2016) has pointed out in earlier research with the same materials the diversity of discourses circulating in the design sessions: aspects of application design, teamwork, teacher education, technology use in language teaching, language teachers' professional practice, and the nature of language learning. The present study explores the collaborative dynamics of action and interaction as well as the competing discourses circulating in the discursive space of the design meetings.

Figure 1 illustrates the arrangement in a typical design session: the technology developers (Alex and Riina) are positioned closer to the data projector screen and the language students (Samuel, Tuomas, Ilkka, Aaro, and Jouni) at the other end of the table as a group.

In the sessions, the interaction order between the participants was quite balanced as the language students were positioned both by the technology developers and by themselves as collaborative partners instead of mere test users. This was done by giving others opportunities for expressing their views and negotiating for meanings, which led to extended discussions in comparison to minimal question- 
answer exchanges. In the language team, Aaro and Samuel were more active in taking turns but they did this by voicing the outcomes of the whole team. The other team members were giving their consent through multimodal means such as nods, gazes, affirmative expressions, and quick consultations in the team. The technology experts' questions prompted longer discussions and sense making in relation to the application, its technical solutions, its use in the field of language pedagogy, and possibilities for further development. The developers' questions were at times what can be expected in usability testing or application development, inviting direct answers. However, more general questions were also asked to prompt discussion around the language teachers' work-life practices. The developers also gave lots of space for the language students to share their views on the working process related to application design. The students wished, for example, more detailed advance information on technical aspects to be able to anticipate some of the constraints of programming in the ideation phase.

Figure 1. The setting in a meeting between the language and technology teams

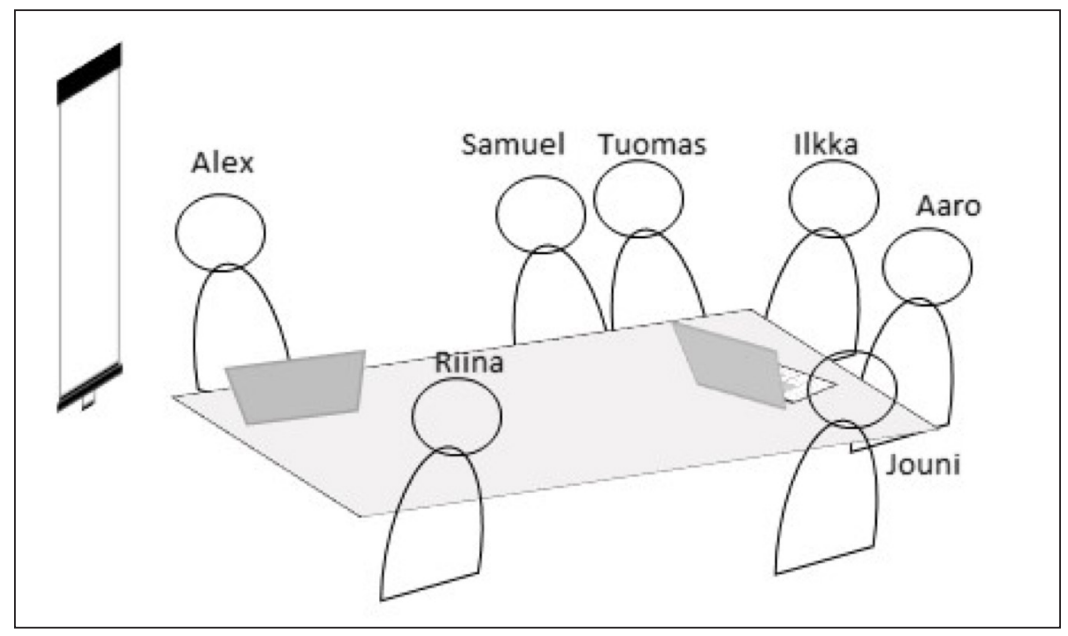

There was also negotiation for meanings in the sessions concerning the focus of evaluation in commenting the use of the application. The technology experts seemed to expect that the evaluation would focus on the application itself, while the students were broadening the discussion to the field of language pedagogy more generally. The technology experts seized this opportunity and joined such exchanges. All in all, the interactions throughout the working process seemed to provide space for genuine collaboration instead of the simple developer vs. test user setting. 
Further, the discussions in the meeting involved tensions related to the experiences of the participants and accustomed practices (historical bodies) in language learning and teaching. Discourses of the tradition were intertwining with discourses of change: classroom-based, textbook-driven teaching of the four skills of language competence in contrast with supporting learning as a situated, sociocultural enterprise more broadly. Moreover, the students were anticipating challenges in trying to surpass traditional language pedagogy as digitally literate professionals, showing agency as future language teachers.

No particularly novel pedagogic solutions for technology development were presented, however. Nevertheless, there were several indications of the language students seeing the broader uses of the application than just completing a game task through a device. Thus, their discourses circulating the design sessions reflected modern views of language learning, also reflected in the curricula. The technology experts were open to these discussions, but their primary aim was to produce a functioning language learning application. The students were in their discussions bringing forth identity elements (Norris, 2011) not only of language teachers, language students, and teacher students, but also of design team members and language experts.

\section{Conclusion}

The study showed how the teams created together, through multimodal means, a fruitful atmosphere for collaboration during the design project as part of a university course for future language teachers. The technology experts stepped aside from the configuration of user testing towards a reciprocal exchange of ideas about the language learning application under construction and, hence, about the nature of language learning, language teaching, and programming, as well as the role of technology in language pedagogy. The discourses around language learning echoed past and current practices anticipating future directions. There seems to be a need for renewal in language teacher education to support students in broadening their view of the profession, taking also an active role in technology design for language pedagogy.

\section{Acknowledgements}

We would like to thank the language students and the technology researchers/ developers for participating in this study. 
Discourses in place: technology and language experts negotiating solutions...

\section{References}

Blin, F., \& Jalkanen, J. (2014). Designing for language learning: agency and languaging in hybrid environments. APPLES - Journal of applied language studies, 8(1), 147-170. http://apples. jyu.fi/ArticleFile/download/433

Norris, S. (2011). Identity in (inter)action: introducing multimodal (inter)action analysis. De Gruyter Mouton. https://doi.org/10.1515/9781934078280

Riekki, M. (2016). Navigating change: nexus-analytic explorations in the field of foreign language education. Acta Universitatis Ouluensis B. Humaniora, 146.

Scollon, R., \& Scollon, S. W. (2004). Nexus analysis. Discourse and the emerging Internet. Routledge. https://doi.org/10.4324/9780203694343 


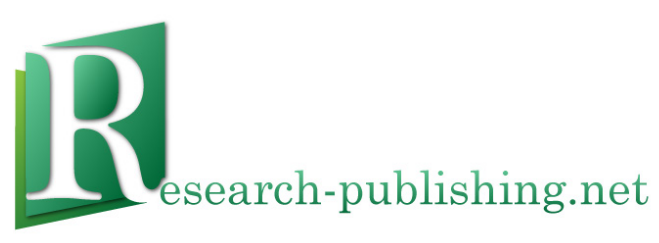

Published by Research-publishing.net, a not-for-profit association Contact: info@research-publishing.net

(C) 2018 by Editors (collective work)

(C) 2018 by Authors (individual work)

Future-proof CALL: language learning as exploration and encounters - short papers from EUROCALL 2018 Edited by Peppi Taalas, Juha Jalkanen, Linda Bradley, and Sylvie Thouësny

\section{Publication date: 2018/12/08}

Rights: the whole volume is published under the Attribution-NonCommercial-NoDerivatives International (CC BYNC-ND) licence; individual articles may have a different licence. Under the CC BY-NC-ND licence, the volume is freely available online (https://doi.org/10.14705/rpnet.2018.26.9782490057221) for anybody to read, download, copy, and redistribute provided that the author(s), editorial team, and publisher are properly cited. Commercial use and derivative works are, however, not permitted.

Disclaimer: Research-publishing.net does not take any responsibility for the content of the pages written by the authors of this book. The authors have recognised that the work described was not published before, or that it was not under consideration for publication elsewhere. While the information in this book is believed to be true and accurate on the date of its going to press, neither the editorial team nor the publisher can accept any legal responsibility for any errors or omissions. The publisher makes no warranty, expressed or implied, with respect to the material contained herein. While Researchpublishing.net is committed to publishing works of integrity, the words are the authors' alone.

Trademark notice: product or corporate names may be trademarks or registered trademarks, and are used only for identification and explanation without intent to infringe.

Copyrighted material: every effort has been made by the editorial team to trace copyright holders and to obtain their permission for the use of copyrighted material in this book. In the event of errors or omissions, please notify the publisher of any corrections that will need to be incorporated in future editions of this book.

Typeset by Research-publishing.net

Cover theme by (C) 2018 Antti Myöhänen (antti.myohanen@gmail.com)

Cover layout by (C) 2018 Raphaël Savina (raphael@savina.net)

Drawings by (C) 2018 Linda Saukko-Rauta (linda@redanredan.fi)

ISBN13: 978-2-490057-22-1 (Ebook, PDF, colour)

ISBN13: 978-2-490057-23-8 (Ebook, EPUB, colour)

ISBN13: 978-2-490057-21-4 (Paperback - Print on demand, black and white)

Print on demand technology is a high-quality, innovative and ecological printing method; with which the book is never 'out of stock' or 'out of print'.

British Library Cataloguing-in-Publication Data.

A cataloguing record for this book is available from the British Library.

Legal deposit, UK: British Library.

Legal deposit, France: Bibliothèque Nationale de France - Dépôt légal: Décembre 2018. 